九州大学学術情報リポジトリ

Kyushu University Institutional Repository

\title{
Food Habits of the Japanese Giant Flying Squirrel, Petaurista leucogenys
}

Ando, Motokazu

Zoological Laboratory, Faculty of Agriculture, Kyushu University

Shiraishi, Satoshi

Zoological Laboratory, Faculty of Agriculture, Kyushu University

Uchida, Teruaki

Zoological Laboratory, Faculty of Agriculture, Kyushu University

https://doi.org/10.5109/23805

出版情報 : 九州大学大学院農学研究院紀要. 29 (4)，pp. 189-202，1985-06. Kyushu University バージョン：

権利関係 : 
J. Fac. Agr., Kyushu Univ., 29 (4), 189-202 (1985)

\title{
Food Habits of the Japanese Giant Flying Squirrel, Pe tauris ta leucogen ys
}

\author{
Motokszu Andō, Satoshi Shiraishi and Teru Aki Uchida
}

Zoological Laboratory, Faculty of Agriculture,

Kyushu University 46-06, Fukuoka 812, Japan

(Received February 12, 1985)

\begin{abstract}
Field observations on the food habits of Petaurista leucogenys were made, together with the measurement of feeding rates in captivity. The animal depended for its food entirely on plant material available on big trees, and got a greater part of the food from a limited number of tree species. A given particular tree species was utilized for a long period of the year although food parts varied according to seasons. The animal fed extensively on young leaves and fruits of deciduous broad-leaved trees during April-June, seeds and acorns during July-November, and mature leaves of evergreen broad-leaved trees and winter-buds during DecemberMarch. Acorns, seeds and fruits were favorite items for the animal. The taste for leaves differed considerably among tree species. Use of coniferous trees was generally lower than of broad-leaved ones. Feeding rates were relatively high in fruits, and low in leaves and bark. Compared with tree squirrels, the dietary characteristic was relatively folivorous during the period in which the favorite foods were not available. Leaf-eating seemed to have an adaptive significance in the arboreal and the gliding mode of life.
\end{abstract}

\section{INTRODUCTION}

The study of food habits is essential for understanding the ecological adaptation of a species to its environment. However, detailed studies on the diet of flying squirrels are still few, compared with a large number of reports on tree and ground squirrels. Petaurista leucogenys is one of the largest animals belonging to Petauristinae, and occurs commonly not only in mountain forests but also in small groves of local villages and shrines throughout Japan except Hokkaido. Although the food habits of the animal was already mentioned in a few reports (Baba et al., 1982; Kawamichi, 1984, etc.), regional differences in the diet have not been studied well. The aim of the present study is to throw light on the relationship between the diet and the ubiquitous distribution of the animal through direct observations at several areas.

\section{STUDY AREAS}

Major observations were carreid out at five areas situated in laurel forest zone; (1) Yakuōin Temple in Hachidji, Tōkyō Metropolis, (2) Suiyō Shrine in 
Amagi, Fukuoka Pref., (3) Kanenotorii on Mt. Hikosan, Fukuoka Pref., (4) Ōnamuchi Shrine in Amagi, Fukuoka Pref., and (5) Yawata shrine in Ogawa, Saitama Pref., together with supplementary observations at other shirne groves and coniferous plantations in Kyushu, Shikoku, Chiibu and Kantō districts. As already mentioned (Andō and Imaizumi, 1982; Andō et al., 1984), study areas (1),(2),(4), and (5) are shrine groves in which giant trees of Quercus spp. and Cryptomeria japonica are abundant. Each of the areas has the following characteristics; deciduous forest occupies a part of the area (1), giant trees of Cinnamomum camphora are abundant at (2), giant trees are composed of only two species, Cryptomeria japonica and Quercus gilva at (4). Moreover, groves at (4) and (5) are isolated from adjoining forests, the former covering an area of 2 ha and the latter of only 0.34 ha. Area (3) is situated in a local village, in which there are many giant roadside trees of Cryptomeria japonica and big garden trees.

\section{METHODS}

The food habits of the animal was examined through direct observations, nightly. In order to quantify the relative consumption of different food items, plant species and food parts eaten were recorded every time when a feeding animal was sighted. The major food parts distinguished were leaves, winter-buds, seeds, acorns, pulp, flowers (including flower buds), bark, twigs and galls. When an individual animal ate two parts or two plant species in a feeding bout, each item was recorded as 0.5 score. Although leftovers dropped on the ground were also used as clues to identify the diet, they were omitted from the quantitative measurements, as the frequency occurrence of leftovers differed according to food items (Andō et al., 1984). Observations were conducted during the period of April 1972 to March 1977 at Yakuoin Temple, November 1977 to April 1980 at Suiyo Shrine, January 1978 to February 1980 at Kanenotorii, January 1981 to February 1982 at Ōnamuchi Shrine, and December 1975 to June 1977 at Yawata Shrine.

In the laboatory, the amount of food intake $(\mathrm{g})$ in a feeding bout and its duration (min.) were measured according to food items. A male adult (HB, $345 \mathrm{~mm}$; BW, $830 \mathrm{~g}$ ) and a female adult (HB, $339 \mathrm{~mm}$; BW, 850g) were used in the experiment. They were usually fed with sunflower seeds and apples, and kept in a wire-netting cage $(60 \times 60 \times 90 \mathrm{~cm})$. In advance of the measurement of feeding rates, the animal was fed with the same kind of food which was used in the experiment, for more than a week for the purpose of habituation.

\section{RESULTS}

\section{The food composition and preference for food items}

The list of food items identified by observing the animal and by checking the leftovers is shown in Table 1 . The diet was composed entirely of plant materials. Among 64 plant species consumed by the animal, almost all were 
Table 1. Food items eaten by the Japanese giant flying squirrel, Petaurista leucogenys, at Yakuōin Temple (YA), Suiyō Shrine (SU), Kanenotorii (KT), Ōnamuchi Shrine (OS), Yawata Shrine (YS) and other study areas.

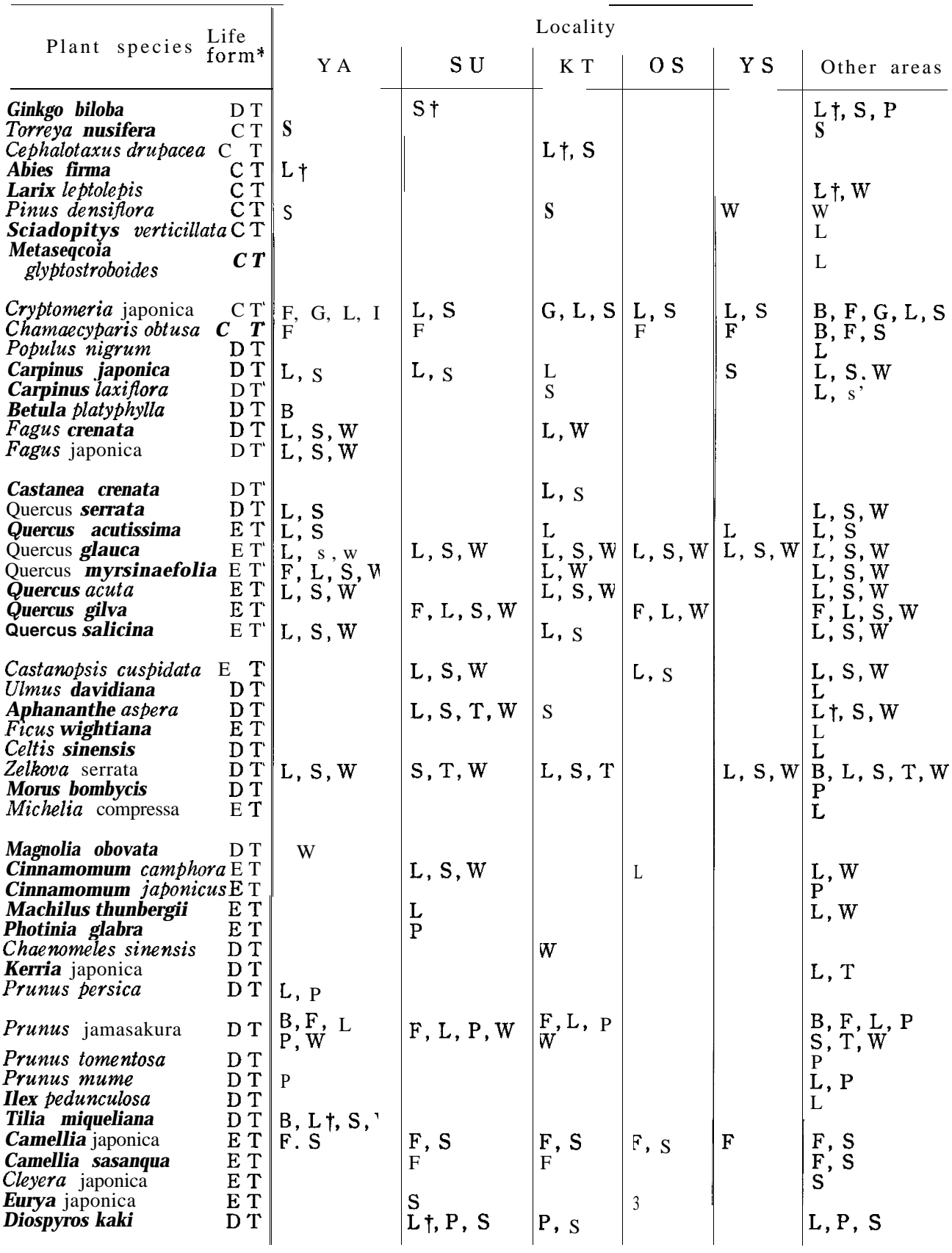


Table 1. (Continued)

\begin{tabular}{|c|c|c|c|c|c|c|c|}
\hline \multirow{2}{*}{\multicolumn{3}{|c|}{ Plant speciesfe form* }} & \multicolumn{4}{|c|}{ Locality } & \multirow[b]{2}{*}{ Other areas } \\
\hline & & & $S U$ & $\mathrm{KT}$ & OS & Y S & \\
\hline $\begin{array}{l}\text { Cornus controuersa } \\
\text { Acer palmatum } \\
\text { Acer mono } \\
\text { Acer japonicum } \\
\text { Sorbus commixta } \\
\text { Robinia pseudo-acacia } \\
\text { Sapindus mukurossi }\end{array}$ & $\begin{array}{l}\mathrm{D} \\
\mathrm{D} \\
\mathrm{D} \\
\mathrm{D} \\
\mathrm{D} \\
\mathrm{D} \\
\mathrm{D} \\
\mathrm{DT} \\
\mathrm{D}\end{array}$ & $\begin{array}{l}\text { L } \\
\text { L, S, W, T } \\
\text { L, S, W } \\
\text { L }\end{array}$ & $\begin{array}{l}\text { F, L } \\
\text { L, S, W } \\
\text { L, S }\end{array}$ & L, S, W & & {$[, W$} & $\begin{array}{l}\text { IL } \\
\text { L, S, W } \\
\text { L, S, W } \\
\text { L } \\
\text { L } \\
\text { L }\end{array}$ \\
\hline $\begin{array}{l}\text { Aesculus turbinata } \\
\text { Hedera rhombea } \\
\text { Trachelospermum } \\
\text { asiaticum } \\
\text { Lonicera japonica } \\
\text { Pueraria lobata } \\
\text { Calystegia japonica } \\
\text { unidentified }\end{array}$ & $\begin{array}{ll}D & T \\
V & T \\
V & T \\
V & T \\
V & G \\
V & G\end{array}$ & $\underset{\mathrm{L}}{\mathrm{F}, \mathrm{L}}$ & $\mathrm{L}$ & $\mathrm{L}, \mathrm{S}$ & & & $\begin{array}{l}\mathrm{L} \\
\mathrm{L}\end{array}$ \\
\hline
\end{tabular}

* CT, coniferous tree: DT, deciduous broad-leaved tree; ET, evergreen broad-leaved tree; VG, vine grass: VT, vine tree.

† Limited to young one.

B, bark; F, flower (including floral bud); G, gall; L, leaf; Li, lichen; P, pulp;

$\mathrm{S}$, seed (including cone and acorn); T, twig; W, winter-bud.

trees with an exception of a few vine grasses coiled round tree trunks. Feeding on a lichen was recorded only once. Most feedings were observed at big trees not less than $10 \mathrm{~m}$ high (Table 2). Even in the same species, big trees were utilized more frequently than small and medium ones.

The annual feeding frequency in terms of plant species, which was worked out by averaging monthly feeding frequencies in the year, is shown in Table 3. In every area, only several tree species constituted a major part of the food amount; especially Quercus spp. played an important role. Regional differences in flora influenced the number and the rank of tree species eaten, e.g. Cinnamomum camphora was the most important food source at Suiyō Shrine, where it was abundant, and only seven species were utilized at the isolated grove of Ōnamuchi Shrine. The relationship between the relative feeding frequency and the relative abundance among big trees at Yakuō-

Table 2. The ratio of the number of tree species eaten by the giant flying squirrel to the total number of tree species according to tree height class.

\begin{tabular}{|c|c|c|c|c|c|c|c|}
\hline \multicolumn{2}{|l|}{ Locality } & \multicolumn{3}{|c|}{ YA } & \multicolumn{3}{|c|}{ SU } \\
\hline Tree height $(\mathrm{m})$ & & $0-4$ & $5-9$ & $10 \leqq$ & $0-4$ & $5-9$ & $10 \leqq$ \\
\hline Number of tree species & (A) & 23 & 40 & 28 & 18 & 14 & 14 \\
\hline $\begin{array}{l}\text { Number of tree species } \\
\text { eaten by the animal }\end{array}$ & (B) & 4 & 22 & 21 & 0 & 5 & 11 \\
\hline $\mathrm{B} / \mathrm{A}$ & & 0.17 & 0.55 & 0.75 & 0.00 & 0.36 & 0.79 \\
\hline
\end{tabular}


Table 3. Annual feeding frequency ( $\%$ ) according to tree species.

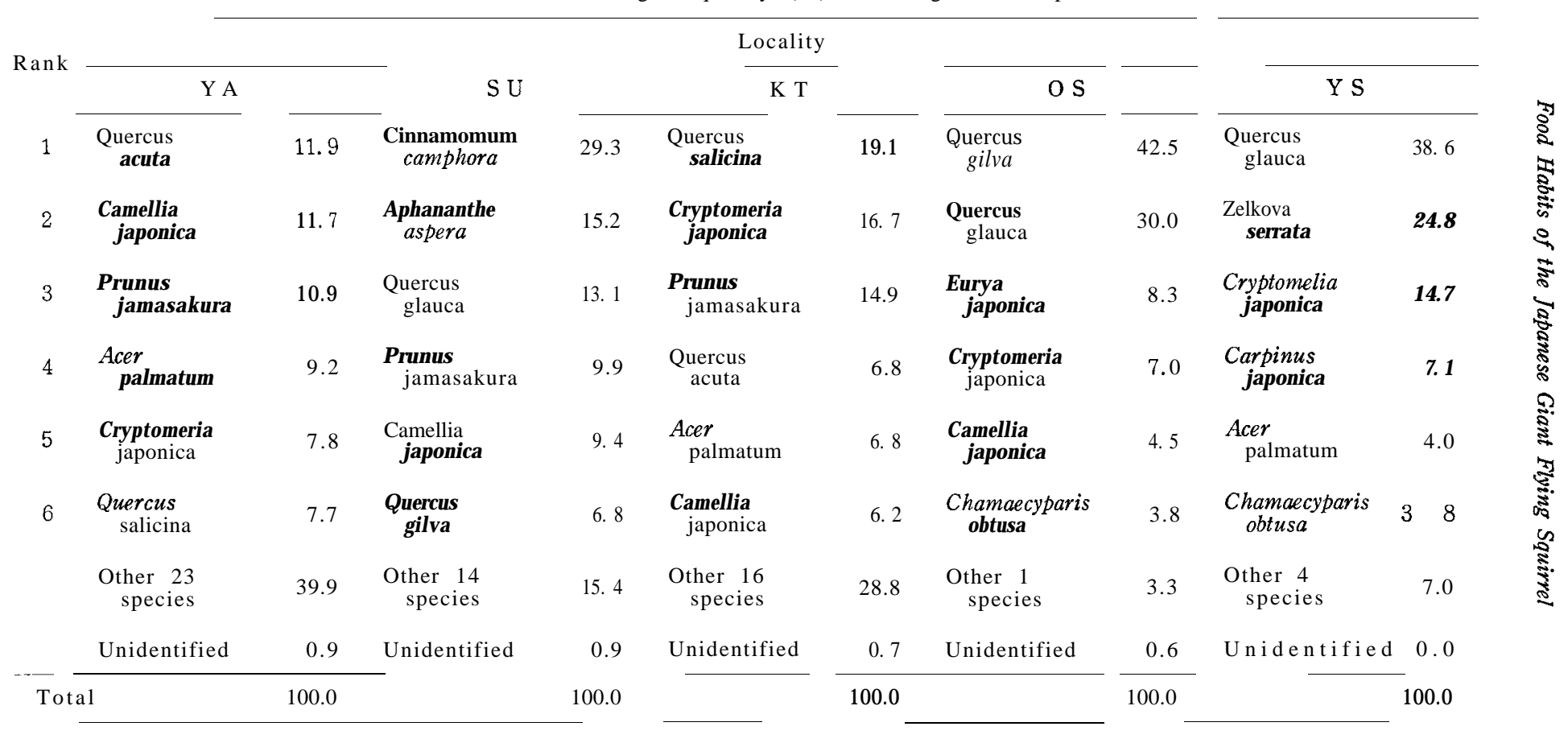


in Temple is shown in Table 4. Selection ratio (relative feeding frequency in percent/relative abundance in percent) varied considerably among tree species. Selection ratios of coniferous, evergreen broad-leaved and deciduous broad-leaved trees, which were calculated by averaging those of the five species from the top in the order, were $0.22,4.68$ and 3.44 , respectively, and it was seen that broad-leaved trees were preferred to coniferous ones.

Annual feeding frequency as to food parts eaten is shown in Table 5. Seeds, acorns, leaves and winter-buds comprised the major part of the food amount. In general, seeds, acorns, pulp and flowers were favorite food items with the animal. In the case of feeding on fruits of Prunus jamasakura or Prunus persica, the animal usually ate only pulp and discarded the seeds. However, it consumed equally the pulp and seeds of Diospyros kaki. When feeding on flowers, they preferred anthers very much, although with small

Table 4. The selection ratios among trees no less than $10 \mathrm{~m}$ high at Yakuōin Temple from 1972 to 1977.

\begin{tabular}{|c|c|c|c|c|c|}
\hline Tree species & $\begin{array}{l}\text { Number } \\
\text { of indi- } \\
\text { viduals }\end{array}$ & $\begin{array}{c}\text { Relative } \\
\text { abundance } \\
(\%)\end{array}$ & $\begin{array}{l}\text { Feeding } \\
\text { frequency } \\
(\%)\end{array}$ & $\begin{array}{l}\text { Selection } \\
\text { ratio* }\end{array}$ & $\begin{array}{l}\text { Life } \\
\text { form }{ }^{\dagger}\end{array}$ \\
\hline Cryptomeria japonica & 106 & 49.0 & 9.5 & 0.2 & $\mathrm{C}$ \\
\hline Abies firma & 24 & 11.0 & 0.5 & 0.1 & $\mathrm{C}$ \\
\hline Chamaecyparis obtusa & 17 & 7.8 & 1.3 & 0.2 & $\mathrm{C}$ \\
\hline Zelkova serrata & 8 & 3.7 & 7. 3 & 2. 0 & $\mathrm{D}$ \\
\hline $\mathbf{Q}$ uercus salicina & 8 & 3.7 & 9.4 & 2.5 & $\mathrm{E}$ \\
\hline Torreya nucifera & 5 & 2.3 & 1.2 & 0.5 & $\mathrm{C}$ \\
\hline Q uercus acuta & 5 & 2. 3 & 14.5 & 6.3 & $\mathrm{E}$ \\
\hline Quercus glauca & 5 & 2.3 & 3.9 & 1.7 & $\mathrm{E}$ \\
\hline Fagus japonica & 5 & 2.3 & 5. 2 & 2. 3 & $\mathrm{D}$ \\
\hline Acer palmatum & 5 & 2.3 & 11.2 & 4.9 & $\mathrm{D}$ \\
\hline Prunus jamasakura & 4 & 1.8 & 13.3 & 7.0 & $\mathrm{D}$ \\
\hline Pinus densiflora & 3 & 1.4 & 0.2 & 0.1 & $\mathrm{C}$ \\
\hline Acer mono & 3 & 1. 4 & 1. 4 & 1.0 & $\mathrm{D}$ \\
\hline Q uercus myrsinaefolia & 2 & 0.9 & 8.3 & 9.2 & $\mathrm{E}$ \\
\hline Magnolia obovata & 2 & 0.9 & 0.4 & 0.4 & $\mathrm{D}$ \\
\hline Aesculus turbinata & 2 & 0.9 & 2.8 & 3.1 & $\mathrm{D}$ \\
\hline Fagus crenata & 1 & 0.5 & 3.0 & 6. 0 & $\mathrm{D}$ \\
\hline Tilia miqueliana & 1 & 0.5 & 2. 4 & 4.8 & $\mathrm{D}$ \\
\hline Quercus serrata & 1 & 0.5 & 2. 1 & 4. 2 & $\mathrm{E}$ \\
\hline Cornus controversa & 1 & 0.5 & 1. 6 & 3.2 & $\mathrm{D}$ \\
\hline Carpinus japonica & 1 & 0.5 & 0.5 & 1.0 & $\mathrm{D}$ \\
\hline Ginkgo biloba & 1 & 0.5 & 0.0 & 0.0 & $\mathrm{D}$ \\
\hline Cephalotaxus harringtonia & & 0.5 & 0.0 & 0.0 & $\mathrm{C}$ \\
\hline Meliosma myriantha & 1 & 0.5 & 0.0 & 0.0 & $\mathrm{D}$ \\
\hline Prunus buergeriana & 1 & 0.5 & 0.0 & 0.0 & $\mathrm{D}$ \\
\hline Kalopanax pictus & 1 & 0.5 & 0.0 & 0.0 & $\mathrm{D}$ \\
\hline Acer carpinifolium & 1 & 0.5 & 0.0 & 0.0 & $\mathrm{D}$ \\
\hline Prunus grayana & 1 & 0.5 & 0.0 & 0.0 & $\mathrm{D}$ \\
\hline Total & 216 & 100.0 & 100.0 & & \\
\hline
\end{tabular}

* Feeding frequency/relative abundance.

$\dagger \mathrm{C}$, coniferous tree; D, deciduous broad-leaved tree; E, evergreen broad-leaved tree. 
Table 5. Annual feeding frequency (\%) according to food parts.

\begin{tabular}{lrrrrr} 
& \multicolumn{3}{c}{ Locality } & \\
\cline { 2 - 5 } \multicolumn{1}{c}{ Food part } & Y A & $\mathrm{s} \mathrm{u}$ & $\mathrm{K} \mathrm{T}$ & $\mathrm{O} \mathrm{S}$ & Y S \\
\hline Evergreen leaves & 16.9 & 25.1 & 28.8 & 20.4 & 15.7 \\
Deciduous leaves & 16.1 & 13.5 & 9.6 & 0.0 & 6.9 \\
Winter buds & 12.6 & 13.5 & 15.2 & 20.5 & 10.9 \\
Seeds and acorns & 22.1 & 25.1 & 26.6 & 24.1 & 31.4 \\
Pulp & 6.9 & 5.8 & 8.1 & 0.0 & 0.0 \\
Flowers & 13.2 & 7.7 & 7.0 & 10.2 & 3.4 \\
Bark & 2.2 & 0.0 & 0.0 & 0.0 & 0.0 \\
Galls & 0.9 & 0.4 & 3.3 & 0.0 & 0.0 \\
Twigs & 0.0 & 0.5 & 0.0 & 0.0 & 0.0 \\
Unidentified & 9.1 & 8.4 & 1.4 & 24.8 & 29.5 \\
\hline Number of records & 535 & 537 & 269 & 93 & 73 \\
\hline
\end{tabular}

flowers, such as P. jamasakura, the entire flower was eaten. Mature leaves, especially those of evergreen trees, and winter-buds were not favorite food items, and utilized only when other favorite items were not available. Mature leaves of Camellia iaponica or Chamaecyparis obtusa were not eaten at all, although these trees were abundant in study areas. Young leaves were eaten much more frequently than mature ones; e.g. leaves of Ginkgo biloba and Abies firma were consumed only when they were very young. Moreover, young leaves of P. jamasakura were chosen as well as flowers. Winter-buds were utilized without distinction of mature leaves in a feeding bout.

Although quantitatively small, bark, galls and twigs were also the food items of the animal. The utilization of bark was limited to a few tree species such as P. jamasakura. The animal usually fed only on the cambium, but it fed on the outer bark of Betula platyphylla on rare occasions. Feeding on galls was limited to those occurring at the twig of Cryptomeria japonica, and their woody parts were eaten. The tips of small twigs in deciduous trees such as Zelkova serrata, were sometimes eaten together with leaves or winterbuds, however, twigs were not eaten alone.

Drinking of free water was not observed in the field. In captivity, the animal did not drink water when it was fed with tree-leaves and apples, but it needed water when fed with sunflower seeds alone.

\section{Seasonal variation in the diet}

The composition of the diet varied remarkably according to seasons, and the year was divided into three periods based on the change in food parts and used tree species (Fig. 1). Characters of each period at Yakuōin Temple were as follows:

\section{I) Young leaf period (April-June)}

The beginning of this period coincided with the flowering time of $\mathbf{P}$. jamasakura. During the short flowering time, the animal fed on it extensively. Leaves of deciduous trees, e. g. Z. serrata and Acer palmatum, began to be eaten concurrently with their first appearance, and were major food items through 
(A)

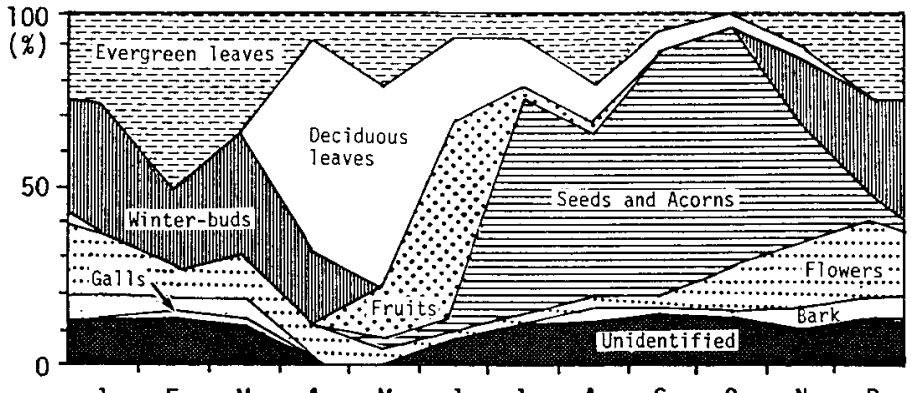

SU

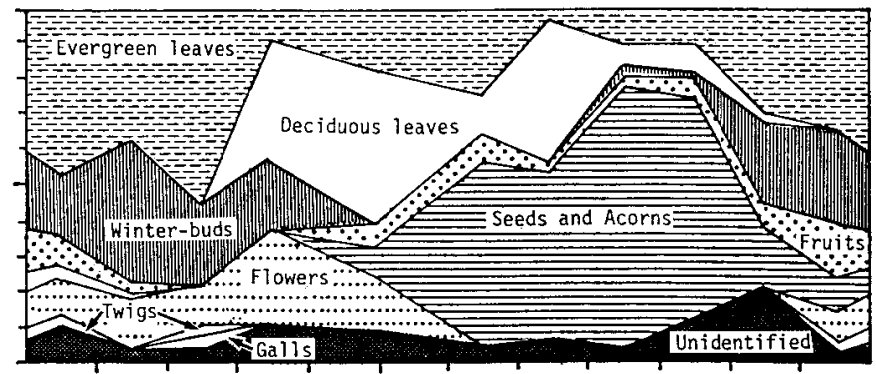

SU
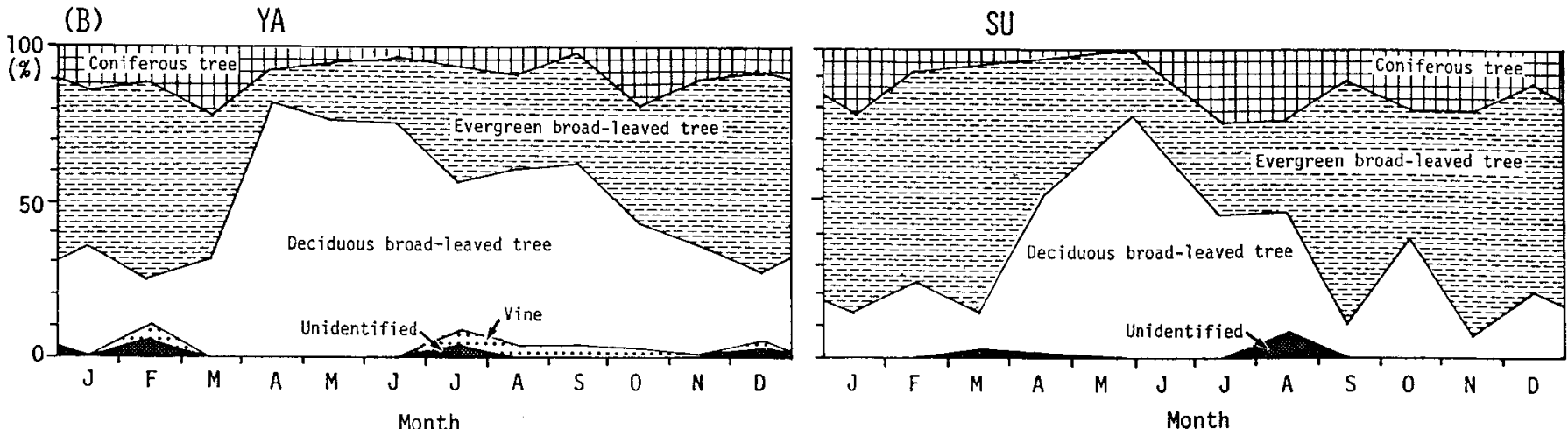

Fig. 1. Seasonal changes of feeding frequency (\%) for different food categories (A) and different life form of trees (B) at Yakuōin Temple (YA) and Suiyō Shrine (SU). 
this period. Young leaves and flowers of Quercus spp. were also utilized frequently. In the latter half of this period, fruits of $\mathbf{P}$. jamasakura and $\mathbf{P}$. persica ripened and became favorite foods of the animal.

\section{2) Acorn period (July- November)}

This period was characterized by an intensive feeding on seeds and acorns of various tree species, e.g. Quercus spp., Tilia miqueliana, Cryptomeria japonica, Z. serrata and Torreya nucifera. Particularly in September and October, these items occupied most of food eaten. Although acorns of Quercus spp. attained full maturity in October, they have already been eaten in June, when they were no more than a few $\mathrm{mm}$ in diameter. Feeding on immature seeds were also common among other tree species. Leaves of deciduous trees such as P. jamasakura continued to be used during this period.

\section{3) Mature leaf and winter-bud period (December-March)}

This period commenced at about the time when most acorns dropped off from trees. Mature leaves of Quercus spp. and winter-buds of various kinds of trees became important food items through this period. Leaves of Cryptomeria japonica were eaten more frequently than those in other periods, and cones of the conifers were eaten consistently since summer. Flowers of Camellia japonica, and male flowers of Cryptomeria japonica and Chamaecyparis obtusa were utilized for a long time through this period. Particularly, the former was chosen by preference. The bark of P. jamasakura and galls of Cryptomeria japonica became also food items in this period.

As to the seasonal variation in tree species used as food source, the relative feeding frequency of deciduous broad-leaved trees increased during the period from April to October, and that of evergreen broad-leaved trees from November to March. Coniferous trees were utilized constantly every month, although the amount of intake was relatively small (Fig. 1). Most of major tree species such as Quercus spp. were utilized for a long period of the year, even all the year round, although the part eaten as food changed seasonally (Fig. 2).

Patterns of seasonal variation in the diet at other fields were also similar to that at Yakuōin Temple, showing slight differences according to the composition of the vegetation. For example, a long feeding period of fruits which extended up to winter at Suiyo Shrine was the result of continuous feeding on D. kaki. At Ōnamuchi Shrine, where deciduous trees were scarcely found, young leaves of Q. gilva were utilized frequently from April to June. At Shinmei Shrine in Akashina, Nagano Pref., where evergreen broad-leaved trees were absent, winter-buds of deciduous trees and leaves of Cryptomeria japonica became the main food items in winter. At Ōhara Shrine in Hita, Öita Pref., where deciduous trees were scarce, mature leaves of evergreen trees such as Cinnamomum camphora were eaten even in seasons other than winter. At the small grove of Kuroyama Shrine situated in large coniferous plantations in Ogose, Saitama Pref., unripe acorns of Quercus glauca started to be eaten in late May, about a month earlier than in other fields. At the isolated grove of Hiruko Shrine in Washiki, Tokushima Pref., mature leaves 


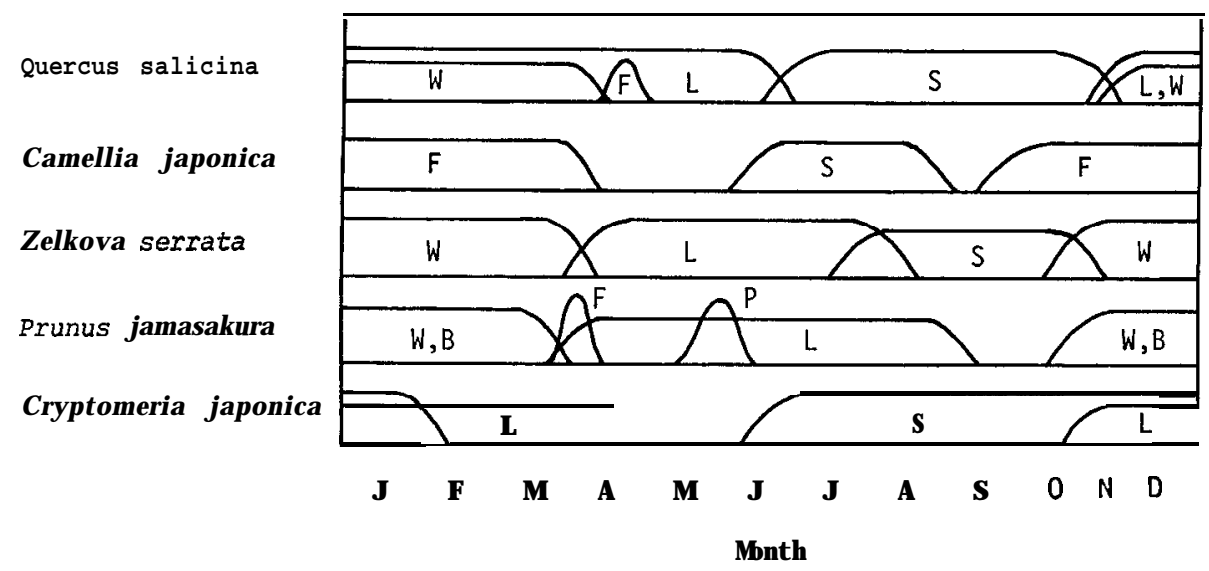

Fig. 2. Seasonal changes of the food parts eaten by the flying squirrel in five tree species at Yakuōin Temple. Abbreviations are the same as in Table 1.

of Sciadopitys verticillata, not eaten at all in other fields, were the important food in winter.

\section{Feeding rates}

The feeding rates varied according to food items, and they were generally high for fruits and low for leaves and bark (Table 6). Feeding rates, indicated by wet weight, showed larger variations among food items than those indicated in dry weight. Feeding rates of soft leaves, e.g. those of Robinia pseudo-acasia, were higher than those of hard evergreen leaves when measured in wet weight, but the rates were similar by dry weight. In the case of leaves of Cryptomeria japonica, it took time to chew the woody part included in the inside of leaves. Feeding rates in small food items were lower than in large ones, because the time spent for selection, picking up and cracking became relatively longer than the time for chewing in small food items. In the case of feeding on seeds of Cryptomeria japonica, most time was spent for gnawing out them from the cones.

\section{DISCUSSION}

\section{Selection of food items}

The animal depends for its food on plant materials available on big trees. Although there are a few reports of a feeding on a chick of Sturnus ciner. aceus (Tachibana, 1955) and an occurrence of chitinous fragments in the stomach contents (Miyao, 1972), animal matter was not fed at all in the present study. Such diet of the animal is reflected also in the high ratio of $\mathrm{C} / \mathrm{N}$ in the stomach contents (Morozumi and Morozumi, 1978). The animal likes acorns, seeds, fruits and flowers as much as many tree squirrels do 
Table 6. The wet and dry weight of food intake per min. according to food items of the giant flying squirrel in captivity.

\begin{tabular}{|c|c|c|c|c|}
\hline Food part & Tree species & $\begin{array}{l}\text { Wet wt. (g) } \\
\text { per min. }\end{array}$ & $\begin{array}{l}\text { Dry wt. }(g) \\
\text { per min. }\end{array}$ & $\mathrm{N}$ \\
\hline Fruits & $\begin{array}{l}\text { Diospyros kaki } \\
\text { Malus pumila } \\
\text { Prunus jamasakura* } \\
\text { Prunus jamasakura† }\end{array}$ & $\begin{array}{l}4.65 \\
4.44 \\
3.74 \\
1.98\end{array}$ & $\begin{array}{l}0.89 \\
0.69 \\
0.49 \\
0.26\end{array}$ & $\begin{array}{r}3 \\
14 \\
3 \\
7\end{array}$ \\
\hline Leaves & $\begin{array}{l}\text { Brassica oleracea } \\
\text { Robinia pseudo-acacia } \\
\text { Cinnamomum camphora } \\
\text { Q uercus salicina } \\
\text { Cryptomeria japonica }\end{array}$ & $\begin{array}{l}1.42 \\
\mathbf{0 . 6 5} \\
\mathbf{0 . 5 8} \\
\mathbf{0 . 2 8} \\
\mathbf{0 . 2 5}\end{array}$ & $\begin{array}{l}0.12 \\
0.20 \\
0.30 \\
0.15 \\
0.10\end{array}$ & $\begin{array}{l}3 \\
3 \\
3 \\
6 \\
6\end{array}$ \\
\hline Seeds and acorns & $\begin{array}{l}\text { Quercus acutissima } \\
\text { Helianthus annuus } \\
\text { Cryptomeria japonica }\end{array}$ & $\begin{array}{l}1.45 \\
0.65 \\
0.25\end{array}$ & $\begin{array}{l}0.95 \\
0.60 \\
0.18\end{array}$ & $\begin{array}{r}8 \\
10 \\
3\end{array}$ \\
\hline Flowers and buds & $\begin{array}{l}\text { Prunus jamasakura } \\
\text { Camellia japonica }\end{array}$ & $\begin{array}{l}1.83 \\
1.46\end{array}$ & $\begin{array}{l}0.45 \\
0.38\end{array}$ & $\begin{array}{l}3 \\
6\end{array}$ \\
\hline Barks & Prunus jamasakura & 0.40 & 0.29 & 3 \\
\hline Twigs & Cinnamomum camphora & 0.67 & 0.50 & 3 \\
\hline
\end{tabular}

* Large cherries put in a saucer.

† Small cherries attached to a twig.

(MacClintock, 1970), but it has an ability to utilize mature leaves and winterbuds during the period when favorite food items are not available on trees. According to Gautier-Hion et al. (1980), it is known that the characteristics in the diet of an animal become clear when food supply is not sufficient, so the leafy diet may be the dietary uniqueness in this species. Leaf-eating is also known commonly among Petaurista living in tropical forests (Muul and Lim, 1978). Relatively heavy weight of the mandible to that of the skull (Miyao et al., 1978) and a long caecum of the animal (Miyao, 1972) seem to be morphological adaptations for fibrous food.

Quantification of food amount by direct observations may be biased by differences in feeding rates among food items (Smith, 1968; Thompson and Thompson, 1980). In the case of the animal, leaves and winter-buds may be overestimated and fruits underrated in the food composition of the animal. Flowers of Camellia japonica may also be overestimated, as this kind of tree is relatively low in height compared with other kind of trees, and the animal perching on the tree can be found easily by observers.

\section{Relationship between the diet and the mode of life}

As seeds are borne on trees only in a limited period of the year, many seed eating squirrels develop the caching habit (Fox, 1981), and depend their winter food on seeds dropped off on the ground or those buried by them in autumn (Thompson and Thompson, 1980). Besides, fruiting condition of acorns is related to the nutritive conditions, and in turn influences on 
the breeding success of these squirrels (Nixon and McClain, 1969; Havera and Smith, 1979). The animal which never goes down to the ground (Andō and Imaizumi, 1982) has to depend its food upon resources available on trees throughout the year. Such food habit relying upon abundant and stable food items as leaves, will make it possible for the animal to maintain a stable population even in a small isolated forest composed of limited tree species. Behavioral and physiological characteristic of the animal, e.g. the lack of caching and hibernating habits and the relatively low exploratory activities, would also be reflections of the abundance of its food (Andō et al., 1984).

With regard to water requirements, tree squirrels such as Tamiasciurus hudsonicus and Sciurus aberti kaibabensis drink free water if it is available, but can fill their need for water from the dew and the water involved in their food when there is no free water (Keith, 1965; Smith, 1968; Hall, 1981). Such an ability would be particularly important for the animal entirely living in trees where open water is not available.

\section{Problems accompanied by a leafy diet}

Few vertebrates use leaves as food although they are abundant and constantly available (McNab, 1978). Several problems must be overcome in the handling of such a leafy diet. Firstly, the leafy diet has a high contents of cellulose and is relatively indigestible for mammals, thus this nature of the diet presumably give them a low energy profit (Short et al., 1974; Bauchop, 1978; Raemakers and Chivers, 1980). Consequently, mammals that feed on leaves to an appreciable extent are characterized by a low BMR, reduction in muscle mass, and the lack of active movement (Fleagle, 1978; Hume, 1982).

Among tree squirrels, appreciable feeding on leaf is confined to the largest species in the tropical rain forest (Emmons, 1980; Payne, 1980). On the other hand, many flying squirrels include leaves in their diet (Fujimaki, 1963; Muul and Lim, 1978). Locomotion by gliding requires essentially very little energy expenditure (Grand, 1978). In addition, gliding animals can survive without active locomotory abilities, because they are relatively safer from predators in trees than terrestrial animals. The fact that many species with a folivorous habit can be seen among gliders, which cover Phalangeridae, Cynocephalidae, Anomauridae and Sciuridae (Marples, 1973;Kingdon, 1974; Nowak and Paradiso, 1983), may have a relation with the facts mentioned above. Moreover, the tendency for leaf-eating increases in proportion to the body size among species of Petauristinae (Muul and Lim, 1978). Larger body size will be advantageous for animals living on nutritionally poor food, because large animals can save the loss of heat from the body surface compared to the small-sized animals (Clutton-Brock and Harvey, 1977; Eisenberg, 1978; Parra, 1978).

Another major problem which tree-leaf feeders meet with is the presence of secondary toxic compounds in their food (Farentinos et al., 1981; Baranga, 1982; Moreno-Black and Bent, 1982). Notable difference seen in the taste of leaves may indicate the presence of this problem in the animal.

As metioned above, it was a dietary characteristic of the animal that 
leaves were included in the diet to a considerable extent when other favorite items were not available, although the animal preferred seeds as much as other tree squirrels do. This diet may have adaptive significance in the arboreal and the gliding mode of life. Besides, the diet made it possible for the animal to live even in small isolated forests composed of limited tree species.

\section{ACKNOWLEDGEMENTS}

We wish to thank Professor E. W. Jameson, Jr., University of California for comments on the manuscript. We are also indebted to the staff of Zoological Laboratory, Kyushu University for their cooperation in the field study.

\section{REFERENCES}

Andō, M. and Y. Imaizumi 1982 Habitat utilization of the white-cheeked giant flying squirrel Petaurista leucogenys in a small shrine grove. J. Mamm. Soc. Japan, 9: 70-81 (in Japanese with English abstract)

Andō, M., S. Shiraishi and T. A. Uchida 1984 Field observations of the feeding behavior in the Japanese giant flying squirrel, Petaurista leucogenys. J. Fac. Agr., Kyushu Univ., 28: 161-175

Baba, M., T. Doi and Y. Ono 1982 Home range utilization and nocturnal activity of the giant flying squirrel, Petaurista leucogenys. Jap.J. Ecol., 32: 189-198

Baranga, D. 1982 Nutrient composition and food preferences of colobus monkeys in Kibale forest, Uganda. Afr.J. Ecol.. 20: 113-121

Bauchop, T. 1978 Digestion of leaves in vertebrate arboreal folivores. In "The Ecology of Arboreal Folivores" ed. by G. G. Montgomery, Smithsonian Institution Press, Washington D. C., pp. 193-204

Clutton-Brock, T. H. and P. H. Harvey 1977 Species differences in feeding and ranging behaviour in primates. In "Primate Ecology" ed. by T. H. Clutton-Brock, Academic Press, New York, pp. 557-584

Eisenberg, J. F. 1978 The evolution of arboreal herbivores in the class Mammalia. In "The Ecology of Arboreal Folivores" ed. by G. G. Montgomery, Smithsonian Institution Press, Washington D. C., pp. 135-152

Emmons, L. H. 1980 Ecology and resource partitioning among nine species of African rain forest squirrels. Ecol. Monogr., 50: 31-54

Farentinos, R. C., P. J. Capretta, R. E. Kepner and V. M. Littlefield 1981 Selective herbivory in tassel-eared squirrels: role of monoterpenes in ponderosa pines chosen as feeding trees. Science, 213: 1273-1275

Fleagle, J. G. 1978 Locomotion, posture and habitat utilization in two sympatric Malaysian leaf-monkeys (Presbytis obscura and Presbytis melalophos). In "The Ecology of Arboreal Folivores" ed. by G. G. Montgomery, Smithsonian Institution Press, Washington D. C., pp. 243-252

Fox, J. F. 1981 Adaptation of gray squirrel behavior to autumn germination by white oak acorns. Evolution, 36: 800-809

Fujimaki, Y. 1963 Observations on the Japanese flying squirrel, Pteromys volans orii Kuroda, in captivity. J. Mamm. Soc. Japan, 2: $42-45$ (in Japanese with English summary)

Gautier-Hion, A., L. H. Emmons and G. Dubost 1980 A comparison of the diets of three major groups of mammals of Gabon (primates, squirrels and ruminants). Oecologia, $45: 182-189$

Grand, T. I. 1978 Adaptations of tissue and limb segments to facilitate moving and 
feeding in arboreal folivores. In "The Ecology of Arboreal Folivores" ed. by G. G. Montgomery, Smithsonian Institution Press, Washington D. C., pp. 231-242

Hall, J. G. 1981 A field study of the Kaibab squirrel (Sciurus aberti kaibabensis) in Grand Canyon National Park. Wildl. Monogr., (75) : l-54

Havera, S. P. and K. E. Smith 1979 A nutritional comparison of selected fox squirrel foods. J. Wildl. Manag., 43: 691-704

Hume, I. D. 1982 Digestive Phylogeny and Nutrition of Marsupials. Cambridge University Press, Cambridge, pp. 69-110.

Kawamichi, T. 1984 Socio-ecology of the Japanese giant flying squirrel (1). Shizen, (456) : 18-26 (in Japanese)

Keith, J. 0. 1965 The abert squirrel and its dependence on ponderosa pine. Ecology, 46: 150-163

Kingdon, J. 1974 East African Mammals, Vol. II part B. Academic Press, New York, pp. 323-353

Marples, T. G. 1973 Studies on the marsupial glider, Schoinobates volans (Keer). Aust. J. Zool., 21: 213-216

MacClintock, D. 1970 Squirrels of North America. Van Nostrand Reinhold Company, New York

McNab, B. K. 1978 Energetics of arboreal folivores: physiological problems and ecological consequences of feeding on an ubiquitous food supply. In "The Ecology of Arboreal Folivores" ed. by G. G. Montgomery, Smithsonian Institution Press, Washington D.C., pp. $153-162$

Miyao, T. 1972 The length of the intestines in the Japanese giant flying squirrel. In "Notes on Japanese Mammals" ed. by T. Miyao, Shinshū-Honyūrui-Kenkyūkai, Matsumoto, pp. 39-40 (in Japanese)

Miyao, T., H. Hanamura and T. Nishizawa 1978 The relative weight of the mandible in Japanese mammals. Growth, 17: 14-27 (in Japanese)

Moreno-Black, G. S. and E. F. Bent 1982 Secondary compounds in the diet of Colobus angolensis. Afr. J. Ecol., 20: 29-36

Morozumi, Y. and T. Morozumi 1978 Mammals. In "Natural History of Suwa" ed. by Suwa-Kyoikukai, Suwa-Kyoikukai, Matsumoto, pp. 29-168 (in Japanese)

Muul, I and B. L. Lim 1978 Comparative morphology, food habits, and ecology of some Malaysian arboreal rodents. In "The Ecology of Arboreal Folivores" ed. by G. G. Montgomery, Smithsonian Institution Press, Washington D. C., pp. 361-368

Nixon, C. M. and M. W. McClain 1969 Breeding seasons and fecundity of female gray squirrels in Ohio. J. Wildl. Manag., 39: 426-438

Nowak, R. M. and Paradiso, J. L. 1983 Walker's Mammals of the World. The Johns Hopkins, Baltimore

Parra, R. 1978 Comparison of foregut and hindgut fermentation in herbivores. In "The Ecology of Arboreal Folivores" ed. by G. G. Montgomery, Smithsonian Institution Press, Washington D. C., pp. 205-230

Payne, J. B. 1980 Competitors. In “Malayan Forest Primates" ed. by D. J. Chivers. Plenum Press, New York, pp. 261-277

Raemakers, J. J. and D. J. Chivers 1980 Socio-ecology of Malayan forest primates. In "Malayan Forest Primates" ed. by D. J. Chivers, Plenum Press, New York, pp. 279-316

Short, H. L., R. M. Blair and C. A. Segelquist 1974 Fiber composition and forage digestibility by small ruminants. J. Wildl. Manag., 38: 197-209

Smith, C. C. 1968 The adaptive nature of social organization in the genus of three squirrels, Tamiasciurus. Ecol. Monogr., $38: 31-63$

Tachibana, S. 1955 Ecology of the Japanese giant flying squirrel. Yacho, 20: 446-447 (in Japanese)

Thompson, D. C. and P. S. Thompson 1980 Food habits and caching behavior of urban gray squirrels. Can. J. Zool., 58: 701-710 